\title{
Crop Fabrication
}

Monalisa Sonkusale; Roshni Lonbale, Vaishnavi Battuwar, Prof. Prasanna Lohe

Computer Engineering Department Nagpur University, Maharashtra, India

\begin{abstract}
Article Info

Volume 7, Issue 3

Page Number: 353-357

Publication Issue :

May-June-2021

\section{Article History}

Accepted : 20 May 2021

Published : 29 May 2021

In India farming is done by traditional methods. Farmers plants crops traditionally without having the knowledge about the contents of the soil and as a result farmer do not gain sufficient profit. The existing method of soil testing is the manual testing starts which by taking soil samples and then sending it to laboratories. The manual process is time consuming and also not feasible. Due to human intervention, there are chances of human errors and so farmers may receive incorrect report. Thus, Development of agriculture using technology is much needed as to minimize the financial losses suffered by the farmers. Thus, our proposed module will provide a brief overview of soil components and other parameters affecting the growth of a crop. Our module is a complete platform designed to such a degree that it incorporates each and every information about the crop from initial level to advance level.

Keywords : Soil Testing, Crop recommendation, Soil contents, Market Scenario, Crop Information
\end{abstract}

\section{INTRODUCTION}

As known soil is the most essential factor for a good crop production. Along with soil, weather condition, irrigation system and other factors too affect the crops and their growth. Basically, focusing upon the soil, for a fruitful crop production. It is essential for the one to have a basic knowledge about the soil components which are helpful for the growth of crop. A healthy soil produces healthy crop with minimal amount of external input and few to number the adverse ecological effect.

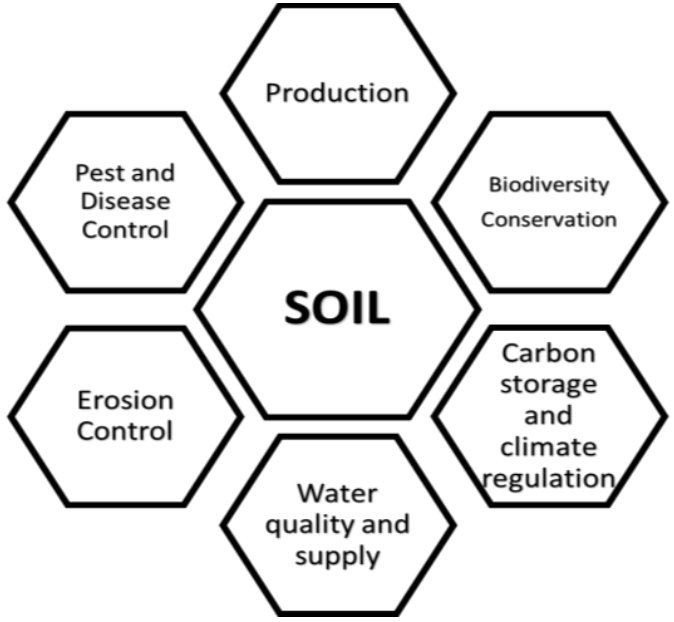

The primary macronutrients $(\mathrm{N}, \mathrm{P}$, and $\mathrm{K})$ are needed in the greatest quantities from the soil and are the plant nutrients most likely to be in short supply in agricultural soils. Secondary macronutrients are needed in smaller quantities, are typically in 
sufficient quantities in soil, and therefore are not often limiting for crop growth. The micronutrients, or sometimes called trace nutrients, are needed in very small amounts and, if in excess, can be toxic to plants. Silicon $(\mathrm{Si})$ and sodium $(\mathrm{Na})$ are sometimes considered to be essential plant nutrients, but due to their ubiquitous presence in soils they are never in short supply.

At Present there is manual soil testing process issued by government and also there many technologies based soil testing methods which can be used but due to various issues faced, farmers avoid these methods.

As Soil is the most essential component for farming, Farmers experiences huge loss due to lack of information regarding the soil contents and others.

\section{PROBLEM DEFINATION}

Farmer must have knowledge about soil fertility and soil components for better crop yield. Farmers must be aware about the soil contents and the best suited crop for the soil. For the same, in 2015, Government of India launched a scheme named "Soil Health Card Scheme" under which the government plans to issue a soil card to a farmer which will carry crop wise recommendation of nutrients and fertilizers required for the individual farms to help the farmers to improve the productivity through judicious use of input. The main parameters the soil card consists are $\mathrm{N}, \mathrm{P}, \mathrm{K}$ (micronutrients), S (secondary nutrients), Zn, $\mathrm{Fe}, \mathrm{Cu}, \mathrm{Mn}, \mathrm{Bo}$ (macronutrients) and $\mathrm{pH}, \mathrm{EC}, \mathrm{OC}$ (physical parameters). Besides this many Android Apps are released for soil testing and other farming related help which were charging different charges. As per the analysis it took minimum of 15-20 days for manual soil testing in laboratories and to generate report for which government is charging different charges for each parameter during soil testing. Also, that soil samples get misplaced and may get wrong reports.

\section{ANALYSIS}

As per our interaction with real farmers at the outskirts of the Nagpur and an interaction with the College of Agriculture, Nagpur we came across many obstacles that a farmer faces for soil testing and then also not getting expected result.

Considering an example of soil testing labs of Nagpur district, situated in the core area of city, the normal soil testing costs as follows:

\begin{tabular}{|c|c|c|c|c|c|}
\hline $\begin{array}{l}\text { Sr. } \\
\text { no: }\end{array}$ & Sample & $\begin{array}{l}\text { Rate/s } \\
\text { ample }\end{array}$ & $\begin{array}{l}\text { Sr } \\
. \mathrm{n} \\
\mathrm{o}\end{array}$ & Sample & $\begin{array}{l}\text { Rate/s } \\
\text { ample }\end{array}$ \\
\hline 1 & $\mathrm{pH}$ & $10 /-$ & 18 & $\mathrm{pH}$ & $10 /-$ \\
\hline 2 & EC & $10 /-$ & 19 & $\mathrm{EC}$ & $10 /-$ \\
\hline 3 & $\begin{array}{l}\text { Available } \\
\mathrm{N}\end{array}$ & $40 /-$ & & & \\
\hline 4 & $\begin{array}{l}\text { Available } \\
\text { P }\end{array}$ & $50 /-$ & 20 & Total N & $50 /-$ \\
\hline 5 & $\begin{array}{l}\text { Available } \\
\mathrm{K}\end{array}$ & $30 /-$ & 21 & $\begin{array}{l}\text { Total } \\
\text { phosphorus }\end{array}$ & $50 /-$ \\
\hline 6 & Organic C & 30 & 22 & $\begin{array}{l}\text { Total } \\
\text { potassium }\end{array}$ & $50 /-$ \\
\hline 7 & $\begin{array}{l}\text { Calcium } \\
\text { carbonate }\end{array}$ & $25 /-$ & 23 & $\begin{array}{l}\text { Micronutrie } \\
\mathrm{nt} \\
(\mathrm{Fe}, \quad \mathrm{Mn} \text {, } \\
\mathrm{Zn}, \mathrm{Cu})\end{array}$ & $\begin{array}{l}100 \\
\text { each }\end{array}$ \\
\hline 8 & $\begin{array}{l}\text { Fe, Cu, } \\
\text { Zn, Mn, } \\
\text { B, Mo }\end{array}$ & $\begin{array}{l}75 \\
\text { each }\end{array}$ & 24 & Total N & $50 /-$ \\
\hline 9 & $\begin{array}{l}\text { Exchange } \\
\text { able } \mathrm{Ca}, \\
\mathrm{Mg}, \mathrm{Na}, \mathrm{K}\end{array}$ & $\begin{array}{l}50 \\
\text { each }\end{array}$ & 25 & $\begin{array}{l}\text { Total } \\
\text { phosphorus }\end{array}$ & $50 /-$ \\
\hline 10 & CEC & $125 /-$ & 28 & $\begin{array}{l}\text { Total } \\
\text { potassium }\end{array}$ & $50 /-$ \\
\hline 11 & $\begin{array}{l}\text { Lime } \\
\text { requireme } \\
\text { nt }\end{array}$ & $50 /-$ & 27 & $\begin{array}{l}\text { Micronutrie } \\
\mathrm{nt} \\
(\mathrm{Fe}, \mathrm{Mn} \text {, } \\
\mathrm{Zn}, \mathrm{Cu})\end{array}$ & $\begin{array}{l}100 \\
\text { each }\end{array}$ \\
\hline 12 & $\begin{array}{l}\text { Gypsum } \\
\text { requireme } \\
\text { nt }\end{array}$ & $50 /-$ & 28 & $\begin{array}{l}\text { Total } \\
\text { N(Manure) }\end{array}$ & $150 /-$ \\
\hline
\end{tabular}


Considering the above rate if a farmer is visiting to the laboratory for soil testing in the city, it will cost him/her travelling charges along with the charges required for soil testing will be added externally. Considering, the farmer wants the additional information other than the initial information, the total cost will be roughly a count of 700/- to 1000/and getting his/her manual report after 15-20 days.

That is in total it will cost around 1500/- to 2000/- for a farmer just for soil testing twice a year which is mandatory. Also, most of the time the farmer does not get accurate analytical data about the soil due to human intervention there are chances of human errors. Hence, it is quite unaffordable for a normal farmer.

\section{IMPLEMENTED PROJECTS}

Concerning about the problems faced by the farmers for soil testing, Government of India issued a scheme named "SOIL HEALTH CARD SCHEME" in which government officials performs laboratory based manual soil testing and provides soil health card to a farmer consists of all the main components of the soil. But there are many problems faced by the farmer like requires lots of paper work and time, also government is charging various charges for testing, there are many chances of getting wrong soil report due to soil misplacement or human errors.

Besides government schemes many mobile applications are develops for the same but according to farmer feedback the services provided by the apps are quite expensive for a normal farmer.

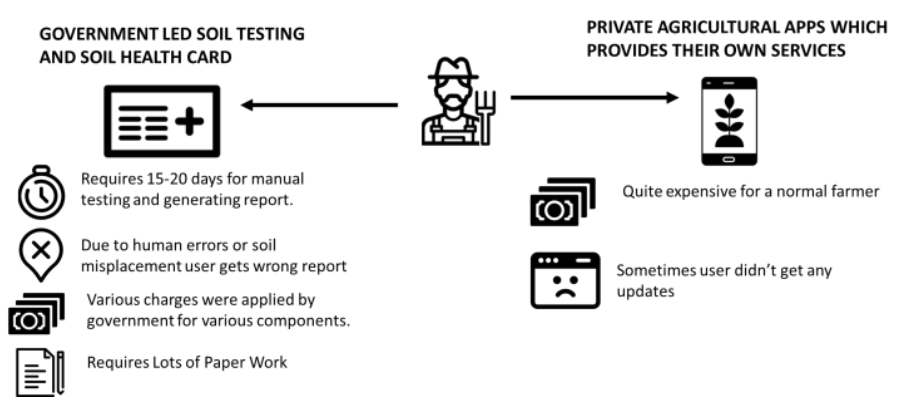

\section{PROPOSED METHODOLOGY}

On the basis of analysis, we conclude that for a soil testing the total cost required to a farmer is about $1500 /-$ to $2200 /-$ twice a year which is unaffordable for the poor farmer. That is why many farmers avoid soil testing and continue with their traditional crop and farming technique's without knowing the contents and information of the soil and thus suffer a great loss.

While experienced planter could identify some issues at early stages human observation are expensive, time consuming and sometime subjective. But usually, the depletion in nutrients of the soil goes unnoticed in early stages. Here we are proposing a module using raspberry pi which will reduce the time and cost required for soil testing. As in today's scenario mobile phones/smartphones are the common things that every individual owes.

Hence, we intend to determine the parameter of soil using sensors (temperature, humidity, moisture, illumination, salinity etc.) and notify the farmer with the alter report directly on his/her mobile phone with complete soil contents including all main parameters used to consider soil health. The generated data will be analysed and the suitable crop recommendation is given to the farmer. Along with the recommended crop the farmer would also get the information about the seeds, fertilizers. Irrigation and water quantity and the diseases that can affect the recommended crop. Along with the recommended crop it will also provide the complete information about that crop which will include the total number of days required for harvest possible pest or insect attacks for that crop, best seeds and fertilizers etc. It will also provide a rough idea for the current and future market value of that crop so as to decide the farmer whether it will be profitable for him or not. It will also notify the farmer about the government scheme which were launched by the government of India. 


\section{SYSTEM ARCHITECTURE}

The proposed module is a complete platform which basically works in various steps. These steps include sensors sensing the values generating the data, analysing the data for report generation, sending message link to the user, giving complete information etc.
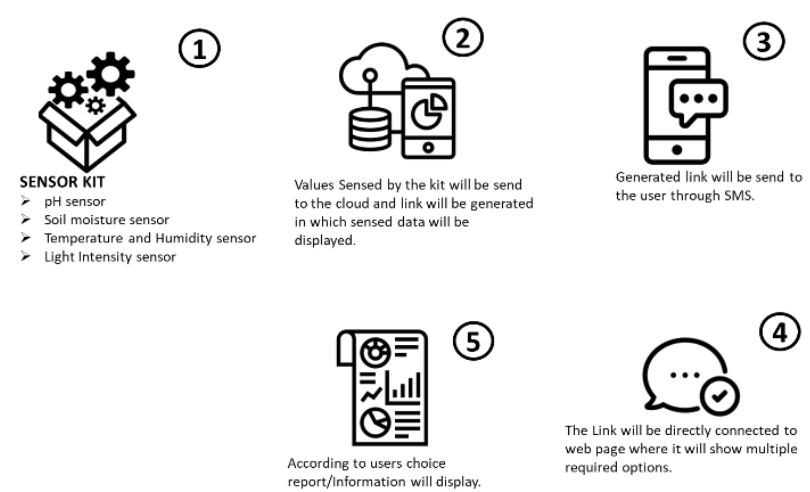

A Complete kit is designed using ESP32 and various sensors for sensing soil values such as moisture sensor, temperature and humidity sensor, light sensor, $\mathrm{pH}$ sensor etc.

The sensors sense the values of the components of the soil and display the valued on LCD screen.

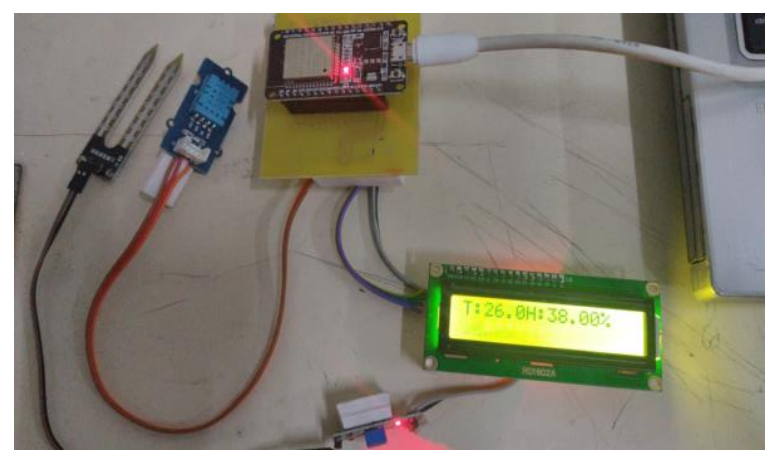

The sensed values are sent to Thingspeak.com cloud platform where the report of all the sensed values is generated and showed in graphical prestation.

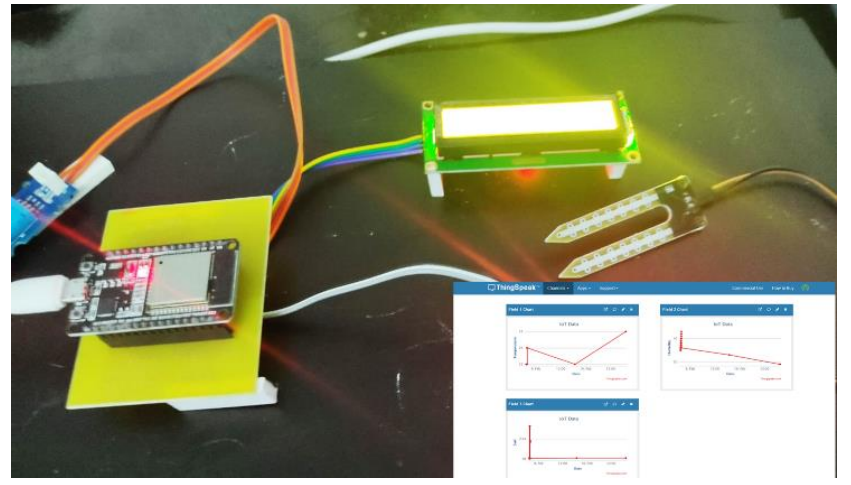

Further the data from the cloud is sent to the user as a web link through message notification. The link generated will be consisting of various options such as generated report, market overview and government schemes in agriculture domain.

The generated report will consist of soil contents sensed by the sensor's recommendation for the best suited crop for the specific soil contents. Along with recommended crop further complete information about the crop is given. The market overview will be consisting information about the past, present and future market scenario for a specific crop. Also, it will have complete information about the various schemes issued by the government for the beneficiary of farmers.

\section{CONCLUSION}

This system provides a real time information of each and every aspect efficiently direct to the farmer without any paper work and in minimum time. In overall scenario it is a combined platform where we incorporate the technologies which will provide a complete information to the farmer from the initial level to the advanced level including pest control, fertilizers etc. It is a one-time purchase product that can be used multiple times during whole cultivation process for taking all the necessary precautions for better yield. 


\section{FUTURE SCOPE}

Further the module can be extended with the advance feature which can include idea for better financial inclusion for farmer for planning out loans, interests and managing the costs also with the idea about government agencies helping farmers, agricultural loan banks, farmer's pesticides firm etc.

\section{REFERENCES}

[1]. Komal Abhang, Surabhi Chaughule, Pranli Chavan, Shraddha Ganjave "Soil Analysis and Crop Fertility Prediction", IRJET, Volume 5, Issue 3, march 2018

[2]. Akshay Badhe, Sandeep Kharadkar, Rushikesh Ware, Pratik Kamble "IOT Based Smart Agriculture And Soil Nutrient Detection System" CE RMDSSOE, Warje, Pune,India.

[3]. Assessment of the SMAP Passive Soil Moisture Product,IEEE TRANSACTIONS ON GEOSCIENCE AND REMOTE SENSING VOL54 no.8 august 2016.

[4]. Applying big data for intelligent AgricultureBased crop Selection Analysis VOL-7 2019.

\section{Cite this article as :}

Monalisa Sonkusale, Roshni Lonbale, Vaishnavi Battuwar, Prof. Prasanna Lohe, "CROP FABRICATION", International Journal of Scientific Research in Computer Science, Engineering and Information Technology (IJSRCSEIT), ISSN : 24563307, Volume 7 Issue 3, pp. 353-357, May-June 2021. Available at doi : https://doi.org/10.32628/CSEIT217348 Journal URL : https://ijsrcseit.com/CSEIT217348 